Letras, Lima, Univ. San Marcos. 63 (91): 28- 48, 1992.

\title{
Filosofía y metáfora
}

MAGDALENA VEXLER TALLEDO

Es un hecho que en el lenguaje filosófico aparecen una serie de analogías y metáforas en sus diversas modalidades, por eso se plantea el problema de saber si su uso en este campo es legítimo - no; si la utilización de la metáforar en Filosofía significa una invasión del lenguaje poético que introduce el error o la cmbigüedad en ella, o más bien su uso está bustificado porque es un medio de expresión especial adecuado para el lenguaje filosófico o porque es un medio de inielección de la realidad.

Hay diversos planteamientos al respecto y éstos dependen de la concepción filosófica que asuma el autor, así como de la concepción que tenga de la naturaleza de la metáfora y sus funciones.

Platón, por ejemplo, ha utilizado con mucha frecuencia alegorías parabólicas, mitosg etéu quie son Cconsiderados formas exiensas de la metáfora, sin embargo no presenta en ninguno de sus escritos alguna teoría acerca de la metáfora y si su uso es legítimo o no en filosofía, aun cuando en muchos pasajes aparece mencionadas las palabras imagen y comparación.

Se piensa que Platón, por el abundante uso que hace de las expresiones metafóricas, no considera ilegítimo el uso del lenguaje figurado, en general dentro de la filosofía.

Respecio a si Aristóteles considera legítimo el uso de la metáfora en Filosolía hay interpretaciones opuestas que se basan en diferenies pasajes de su obra.

Así, algumos autores consideran que para Aristóteles no era adecuado el uso de la metáfora en Filosofía y basan su afirmación en los siguientes pasajes:

"Podemos añadir a esto que, si la disputa dialéctica no hace uso de metáforas, evidentemente las metáforas y las expresiones metafóricas quedan excluídas de la definición: de lo con- 
trario, también la dialéctica envolvería las metáforas y las utilizaría" (1) y

"... Siempre que algún problema se muestra intratable, o bien necesila definición, o bien connota diversos sentidos, 0 bien implica un sentido metafórico" (2)

Pero, sobre todo, los que consideran que Aristóteles criticc el uso de la metáfora se basan en el siguiente pasaje:

"Pues una expresión metafórica resulta siempre oscura" (3)

Sin embargo, según E. Martino, esta afirmación hay que interpretarla en el "contexto restrictivo de la definición" (4), esto es que se refiere a la definición la cual está excluyendo la metáfora.

La afirmación de que la expresión metafórica es oscura, tiene, entonces un carácter particular referido a la definición.

Sin embargo, basándose en el mismo párrafo de Analíticos Posteriores $97 \mathrm{~b}$, Mariino afirma:

"Se ve claramente que Aristóteles no llega al fondo de la cuestión a la hora de excluir de la definición a la metáfora. Comienza derivando esa excluisión a partir del hecho de que no se ha de disputar con meláforas, lo cual no es en absoluto exacto, a juzgar por la rectificación inmediata que se adjunta. Es cierto, en conclusión, que proscribe la metáfora del ámbito de la definición, pero ya no lo es tanto el que se la excluya dejlododiscusiónzy meños quíng de la exposición doctrinal" (5).

"Jorge Puccinelli Converso"

De ahí que Martino rechaza la tesis de que Aristóteles aprueba el uso de la metáfora sólo como ornato de estilo y rechace por completo su uso en el raciocinio. Esto estaría en contradicción con la reducción esencial del contenido conceptual de la comparación a la metáfora que hace, según esta interpretación, Äristóteles, así como la práctica del propio filósofo.

En la Edad Media, los filósofos escolásticos inclinados a la tradición aristotélica critican el uso de alegorías y metáioras en Platón, a pesar de que también utilizan algunas analogías y metáforas, por ejemplo:

(1) Aristóteles, Analiticos Posteriores 97b.

(2) Aristóteles, Tópicos $158 \mathrm{~b}$.

(3) Ibid, 13 a b.

(4) Martino, Aristóteles, el alma y la comparación, Ed. Gredos, Madrid 1975, pág. 145.

(5) Ibid, Pág. 146. 
"Metáfora de la esfera infinila" "Comparación de la difusión de los rayos del sol con la difusión creadora de Dios" (Sent. d43). "Comparación entre el espejo y el pensamiento de Dios sobre las cosas (de Verti, q12)] (6).

Expresiones que aparecen en Sto. Tomás de Aquino.

En la Edad Moderna el tema de la metáfora no fue, mayomente, materia de la reflexión de los filósofos, sin embargo hay opiniones en contra de su uso, así por ejemplo Hobbes, sitúa a las metáforas dentro de los cuatro abusos del lenguaje los cuales son: registrar mal el pensamiento, el uso metafórico, declarar una voluntad que no es la propia, y el agravio. Estos cuatro abusos se oponen a los cuatro usos correctos y especiales del lenguaje que son: comunicar las cosas, transmitir conocimiento, expresar voliciones y satisfacernos y deleitarnos a través del lenguaje ornamental.

Hobbes lo expresa así:

"A estos usos corresponden también cuatro abusos. En primex lugar, cuando los hombres registran mal sus pensamientos... Segundo, cuando ușan metafóricamente las palabras, esto es, en un sentido distinlo de aqué! para el que fueron o.de nadas y con ello engañan a otros... (7)

Como se podrá advertir, Hobbes condena el uso de la metćfora incluso con uná finalidad esłética, puess dentro de los cuotro usos del lenguaje incluye el de "salisfacernos y deleitamos a nosotros mismós qy a otros jugahdo cber nulestras palabras inoceniemente, por placer o por ornámento" (8) y a la metáfora no la incluye dentro de los usos del lenguaje sino dentro de lo que el denomina abusos del lenguaje.

Hobbes, también, considera a la metáfora, y al lenguaje figurado en general, como causa de absurdos, o lenguajes sin sentido y la ubica dentro de los siete tipos de absurdos:

"La primera causa de conclusiones absurdas la atribuyo a la carencia de método... La sexta, al uso de metáforas, tropos y otras figuras retóricas en vez de las parabras apropiadas,

(6) Ferrater Mora, Diccionario de Filosofía, II Ed. Sudamerica, Bs. As. 1971 pảg. 190. Pág. 140 .

(7) Hobbes, Thomas, Leviatán, Ed. Nacional, Madrid 1980, (8) Hobbes, Loc. Cit. 
pues aunque es legítimo decir (por ejemplo) en lenguaje común que el camino va o lleva a tal o cual parte, que el proverbio dice esto o aquello (cuando los caminos no pueden ir, ni los proverbios hablar), a la hora de calcular y buscrer la verdad iales modos de hablar no deben admitirse" (9)

Hobbes, sostiene que el hombre es el único ser que comete estos absurdos

"y de los homb:es quienes más sometidos esićn a ellos son quienes profesen la fllosofía" (10).

Este filósofo, a pesar de que el mismo utiliza este tipo de lenguaje, excluye totalmente, por incrpropiado, la utilización de la metáfora cuando afirma:

"la luz de las mentes humanas está en las paiabras ciaras, pero venleadas primero mediante definiciones exactas y depuradas de ambigüedad. La jazón es la senda; el incremenio de ciencia, el camino. Y el beneficio de la humanidad, el fin. Al contrario las metáioras y las palabras ambiguas y sin sentido son como ignes fatui; y razonar sobre ellas es vagar entie innumerables absurdos. (Y su fin es el litigio, la sedición o el desden" (11).

Todas esios afirmaciones se derivan de su concepción fi'osófica en general, yäique̊ para este filósofo a razonamiento es cálculo y su principal medio es la definición.

Hume, también, "crpfóe el uso de la inetafora" y utiliza su refutación para demostrar el absurdo. Esto lo realiza, por ejemplo, cuando refuta el argumento en favor de la naturaleza de Dios, a partir del orden y diseño hallado en el mundo, mostrando los lugares comunes asociados. Sin embargo, como afirma Turbayne, con esto no se invalida el uso de la metáfora en general.

Posteriormente se dan, también, diversas opiniones respecto a la presencia de la analogía y metáfora en el lenguaje filosófico.

Para $\tilde{A}$. Biese, quien identifica metáfora en e! lenguaje filosófico, y personificación, el pensamiento filosófico trabaja sobre imágenes de la fantasía, los cuales son metáforas. Estas metáforas son representaciones del mundo exterior a través de analogías con nuestra vida interior. De acuerdo a esto, la filosofía sería básicc-

(9) Ibid, Pág, 152-153.

(10) Ibid, Pág. 152.

(11) Ibid, Pág. 155. 
mente antropomórfica, pues sólo podríamos conocer la realidad externa por referencia a nuestra vida interna.

De acuerdo a Biese:

"el mundo no se nos torna verdaderamente conocido sino en la medida en que lo vivimos, porque lo transformamos según las leyes de nuestro espíritu y le adjudicamos nuestros propios aiributos espirituales y corporales" (12).

De manera que el conocimiento sólo podría producirse

"en las formas de la meiáfora, o sea por analogías con nuestra propia vida interior" (13).

Las metáforas adquieren mayor importancia en la filosofía, porque a través del lenguaje hablado, las metáforas creadas pasan a un sistema de nociones del pensamiento influyéndolo grandemente.

Las pruebas de estas afirmaciones estarían dadas, según Biese, a través de toda la historia de la filosofía, así las ideas de Platón vendrían a ser las concreciones de nociones humanas, el concepto de sustancia de Spinoza tiene como atributos la extensión y el pensamiento que son los que el hombre como ser físico posee, asimismo considera que el yo de Fichte, el absoluto de Hegel, la voluniad de Schopenahuer y el inconsciente de Hartman, vienen a ser personificaciones metafísicas de la realidad última.

Hegel, al sostenen lquelastleyes de desarrollo de la realidad son las mismas que daspleyes de to inteligencia humana estaría utilizando una metáfora analógica en base a las propiedades de la persona humana.

Vianu hace una crítica a esta posición, señalando que Biese identifica metáfora con personificación lo cual no es exacto, pues se conocen otras formas metafóricas.

Vianu, afirma:

"El antropocentrismo ocupa uno de los lugares más amplios en las concepciones filosóficas antiguas y recientes. Y con todo el antropocentrismo no es una posición obligatoria del espíritu conocedor. Además, es una posición que el espíritu

(12) Citado por Vianu, en: Los problemas de la Metáfora, Eude BA, Bs. As. Pág. 38.

(13) Vianu, Ob. Cit., Pág. 39. 
procura eliminar, por lo común, en las etapas más nuevas en su descriollo" (14).

Continuando con su crítica, Vianu nos dice que el conocimiento se puede producir modelando lo externo con referencia a lo interno y a la inversa modelar lo interno con referencia a lo externo; la primera actitud corresponde al antropocentrismo y si bien el conocimiento se poduce por analogía de lo desconocido a lo conocido. no tiene que ser necesariamente con referencia a los estados interiores sino más bien con referencia a la experiencia más cercana.

La presencia del elemento personificador en las antiguas sistematizaciones filosóflcas consituyen, según Vianu, causa de error y más bien debe se: eliminado.

Además, el proceso de personificación, sólo tuvo importancia en los inicios de la reflexión filosófica, y una vez formada la noción correspondiente, aun cuando hubiese tenido un origen perscnificador se va despojando de este lastre, por ejemplo, el concepio de fuerza, si bien en Empédocles tiene un carácter antropocéntrico, el uso dado posteriormente a este término ha elíminado esa comnotación, tal como en Newion en el que este tórmino ya se ha purificado de esta refereneia personificadora.

"El método (personificador) perdio después su antigua importancia, a medida que el espiritu iba conquistando dominios cada vez más dilatados del inundo exterior, de manera que la reapaición de las petson ficaciones en los concepios más recientes es signo de un arcaismo intelectual, que debe censurar la crílica filosófica y no revelación de algunas condiciones permanentesi del odrocimientol como Biese pretendia hacernos creer" ( 15 ) .

Pero hay que agregar que la crítica que hace Vianu a Biese apunta, más que a la meáfora, en general, a una de sus formas la personificación, como bien lo dice el propio Vianu. Por tanto no se habría demostrado la ilegitimidad del uso de la metáfora en el conocimiento y la filosofía. Además, no es tampoco cierto, que la personificación se haya utilizado sólo en los primeros estedios del proceso de descrrollo del hombre. Esie es un medio, que si bien actualmente se usa con menos frecuencia, continúa vigenle por ejemplo para referirse a la conservación de información en las máquinas computadoras el hombre utiliza el nombre de "memoria"; a la parte superior de un cohete, se le denomina "cabeza"; a la parie delantera de un avión "nariz", etc.

Otro de los pensadores que ha tratado el tema de la metáfora y su uso en Filosofía ha sido H. Bergson. Sus tesis acerca de la

(14) Ibid, Pág. 40.

(15) Ibid, Pág. 41. 
metáfora se deriva de su concepción filosófica, y sobre todo de sus planteamientos acerca de la intuición.

Bergson, opone la intuición a la inteligencia, así como el tiempo al espacio. La intuición es el lenguaje del tiempo mientrar que la inteligencia es el lenguaje del espacio.

La idea fundamental de su filosofía es que lo esencial de la elernidad es la duración, es el despliegue del tiempo, todo ocurre en la duración, las cosas no son, sino fluyen en el tiempo. Esta idea metafísica determina el método del conocimiento.

La inteligencia no sería el órgano adecuado para captar la realidad porque es estática y no puede comprender la vida que es duración y movimienío.

El lenguaje corriente es inapropiado porra expresar la realidad, el lenguaje es espacializador, por lo que hay que buscar un método afín a la duración, de naturaleza temporal y éste es la intuición. Ia intuición es captación de la duración, es un golpe de sonda en la pura duración y se opone a la inteligencia que es analítica.

El lenguaje que es espacializador y la inteligencia que es estática debe expresarse en imágenes y metáforas para captar y expresar la duración.

La imagen constituye un intermedio entre la simplicidad de la intuición y la complejidad de las abstracciones de la inteligencia. La imagen no es la intuición misma pero se aproxima más a ella que los conceptos formados por la inteligencia que, como se ha indicado es espacielizadora y no penetra en el espíritu.

Las metáforas son pues los medios más adecuados para pensar en el espíritu, yi son detseque em este taspesto lo expresan con más propiedad ya que los conceptos abstractos, aptos sólo para las cosos materiales, ison los que al qeferirse al espíritu lo están haçiendo en un sentido figurado.

El corrientemente llamado "lenguaje figurado" o lenguaje metafórico es el lenguaje de la filasofía ya que así se logra expresar la verdadera realidad que es la duración. Es el lenguaje "propio" de la filosofía y sólo debe sugerir y no descubrir o representar como lo hoce el lenguaje abstracto.

Tanto la concepción de Biese como la de Bergson se pueden enmarcar dentro del movimiento del romanticisco que tienden a emparentar tanio la poesía con la filosofía y tienen en común la consideración de que el lenguaje y el pensamiento es insuficiente ante los objelivos del filosofar. En el caso de Bergson él lo ha expresado claramente:

"la experiencia melatísica se enlaza con la de los grandes místicos" (16).

(16) Bergson, Henry, Pensamiento y movimiento. Ed. Reverté 1945, Pág. 1069. 
Las concepciones de Biese y Bergson se diferencian, según Vianu, en que Biese considera que la metáfora es el símbolo mismo de la concepción filosófica, mientras que para Bergson es sólo su medio de comunicación.

En la misma línea de los dos pensadores anteriores, esla el filósofo peruano Mariano Iberico, para quien la metáfora, cuyas características principales son la anciogía y la participación, es parte de la "función hipostática" del lenguaje que opone a la función absiractiva. A través de la metáfora:

"todos los seres, inmersos en el océano de la misma vida, participan en ella de tal modo que la exclusividad de su naturaleza particular se pierde en esta como universal comunión de las esencias y las formas... la analogía establece entre las formas entre sí y entre ellas y las sustancias y acciones de los objetos que bajo esas formas entre sí y entre ellas y las sustancias y acciones de los objetos que bajo esas formass se realizan, un particular parentesco metafísico según el cual lo que se hace con una forma se hace también con la semejante, como si la anclogía tendiese entre las criaturas un hilo sensible, algo así como un sistema de universal repercusión o de universal simpatía" (17).

donde además está contenida la idea del universo como una gran unidad, como un gran todo que la metáfora permile conocer o sentir.

Aquí está presente la idece de lârelaciónaentre los seres vivos $y$ el universo y principglmente del hombre, con el todo del mundo, como manifesición de una identidad indisoluble. Es la concepción que está presente en las llamadas "metáforas cosmológicas" que aparece por ejemplo, en el Timeo de Platón o en la concepción de Nicolás de Cusa y Companella en el Renacimiento.

Sin embargo se considera que:

"la identidad entre el microcosmo es una hipótesis anterior a la evolucionista" (18).

La concepción de lo existente como una identidad total es una concepción mística ya superada por la ciencia actual.

Para Ortega y Gasset: Págs. $45-46$.

(17) Iberico, Mariano; La Aparición, Ed. Santa María, Lima 1950.

(18) Vianu, Ob. Cit, Pág. 89. 
"cuando un escritor censura el uso de metáforas en filosofía, revela simplemente su desconocimiento de lo que es metáfora. $\bar{A}$ ningún filósofo se le ccurriría emitir tal censura" (19).

Oriega, considera que la metáfora es un instrumento intelectual del cucil no se puede prescindir y es una forma del pensamiento científico. Lo que puede suceder es que el científico se equivoque y tome en sentido literal lo que sólo está expresado en sentido indirecio o metafórico, pero:

"el error en el uso de un método no es una objeción contra el método" (20).

Oriegcu distingue dos típos de meláfora: la metáfora literaria y la metáfora científica.

En poesía la metáfora ocupa un papel constituyente, mientras que en la ciencia (y filosofía) la meiáfora ocupa un oficio suplente. Desde el punto de vista estético la metáfora:

"interesa por su fulguración deliciosa de belleza. De aquí que no se haya hecho constar debidamente que la metáiora es una verdad, es un conocimiento de realidades" (21).

De la metáfora, la ciencia toma lo que deja la poesía.

La ley científica se limila a ofirmar la identidad entre las partes abstracias de dos cosas la metáfora poética insinúa la identificación total de dos coser eoncretas.

"Esto muestra que lás actividades intelectuales empleadas en la ciencia son, poco más o menos, la mismas que operan en poesía y la acción vital. La diferencia consiste no tanto en ellas como en el distinto régimen y finclidad a que en cada uno de esos ótdenes son sometidas. Así aconlece con el pensamiento melafórico. Activo donde quiera, rinde en la ciencia un oficio distinto, y aun opuesto, al que espera de él la poesía. Esta aprovecha la identidad parcial de dos cosas para afirmar -falsamente- su identidad total. Tal exageración de la identidad, más allá de su límite verídico, es lo que le da un valor poético. La metáfora empieza a irradiar belleza donde su porción verdadera concluye. Pero.

(19) Ortega y Gasset. José "Las dos grancles metáforas" en Obras Completas, tomo II, Revista de Occidente, Madrid 1963, Pág. 387.

(20) Ortega, Loc. Cit.

(21) Ortega, Ob. Cit. Pág. 392. 
viceversa, no hay metáfofe poética sin un descubrimiento de identidades electivas.

Anclícese cualquiera de ellas, y se encontiará en su seno, $\sin$ vaguedad a!guna, esa identidad positiva, diríamos cienlífica, entre elemenios absiracios de dos cosas.

La ciencia usa al revés el instrumento metafórico. Parte de la ideniaiad to al entre dos objelos concretos, a sabiendas de que es felisc, para quedarle luego con la poición verídica que ella incluye ... Al contrario que la poesia, la meláfora científica va del más al menos"' (22).

Para Ortega, la metáfora tiene dentro de la ciencia dos usos diferentes: a) Para designar fenómenos nuevos que el investigador descubre. En esia operación se recurre a palabras ya ulilizadas dándolo un nuevo sentido, en base a la semejanza con el antiguo significado. De esle modo se constituye la metáfora para comunicar y hacer ontender lo nuevo que se ha descubierto. Así, par ejemplo, Platón para designar las cosas invisibles e inmutables, que según él constiluyen la verdadera realidad, tomó del lenguaje vu'gar la palabra "figura": idea, como indicando que el intelecto ve en un sentido más periecto que los ojos.

b) Para pensar nosotros mismos ciertos objetos difíciles. Es. te uso es el más profundo y esencial de la meláfora desde el punto de vista del conocimiento.

Este segundo uso de la metáfora se hace necesario porque:

"no son... todos los objetos iqualmente aplos para que los pensemos, para due tengámós de ellosiuna idea aparte, de perfil bien definidorge claro:inNulestronessisjtu tenderá en consecuencia, a apoyarse en los objetos fáciles y asequibles para poder pensar los difíciles y esquivos" (23).

Por tanto la metáfora no es sólo un medio de expresión sino, también, un medio esencial de inlelección. En filosofía, pues, no sólo está justificado el uso de la meíálora, sino que es en ella una necesidad ya que el pensamiento filosófico más que ningún otro tiene que tratar de cambiar finamente el sentido de los términos para lograr penetrar en la realidad.

El uso del lenguaje metafórico en Filosofía no es pues un error, concluye Ortega, sino más bien constituye un aporte del filósofo que lo ha utilizado. Solo un:

(22) Ibid, Pág. 393

(23) Ibid, Pág. 391. 
"espírilu inapto o ineducado en la meditación será incapaz al leer un libro filosófico, de tomar como sólo metáíora el pensamiento que es sólo metafórico. Tomará in modo recto lo que está dicho in modo obliquo, y airibuirá al aulor un defecto que, en realidad, el aporta" (24).

Uno de los aspectos donde se ha hecho necesario la utilización de las metáforas ha sido el vinculado con la caracterización de la conciencia.

Siendo esta una realidad que está presente como fondo en todas nuestras actividades psíquicas es algo muy difícil de concebir, percibir, descubrir, y definir. Gracias a la conciencia nos damos cuenta de las demás cosas ya que está presente en cualquier otro fenómeno que vivamos.

"Este fenómeno universal de la relación entre el sujeto y el objeto que es el darse cuenta, sólo podrá concebirse comparándola con alguna forma particular de las relaciones entre objetos. El resultado será una metáfora" (24).

Ahora bien, de acuerdo a Orteca, de la idea que se tenga de la conciencia depende, la concepción del mundo que se erija.

De manera que los principales sislemas de pensamiento filosóficos vienen a descansar en una metáfora.

"En efecto: las dos mayores-épocas del pensamiento humano -la Edad Antigua, con su prolongación medieval y la Edad Moderna, Sque jnicia eleRenacimiento- han vivido de dos similes: come Esquileel diríg, de da, sombra de dos sueños. Estas dos grandes metáforas de la historia de la filosofía son, poéticamente consideradas, de un rango mínimo. El poeta más modesto las desdeñaría" (25).

Estas dos metáforas son: en la edad antigua y medieval el de la conciencia como tabla cerina, $\mathrm{Y}$ en el Renacimiento $\mathrm{Y}$ Edad Moderna el de la conciencia como continente y conienido.

En la metáfora de la tabla cerina, se concibe la conciencia y la mente como una tabla de cera que se imprime con un sello. La relación sujeto-objeto se entiende como una relación análoga a la de dos cosas materiales cuando chocan.

Esta metáfora se encuentra ya en el Theetetos de Platón y es repetida por Arisióteles en "Sobre el A.lma", III, Cop. IV (Lo que

(24) Ibid, Pág. 388.

(24) Ibid, Pág. 396.

(25) Ibid, Pág. 397. 
la mente piensa debe estar en ella de la misma manera o en el mismo sentido en que las letras estón en la tablilla que no contiene ningua escritura actual; esto es exactamente lo que ocurre en el caso de la mente) y va a ejercer gran influencia en la Edad Media.

De esta metáfora, nos dice Ortega, se deriva la concepción del mundo de lo ontigüedad, el "ser" quiere decir una cosa entre las otras, el sujeto es uno de los tantos seres en el mundo, el "yo" no tiene gran papel en la noción antigua del mundo, y en el aspecto ético se busca la acomodación del ser al cosmos.

En el Renacimiento cambia radicalmente la interpretación de la conciencia $y$ aparece la metáfora del continente y contenido.

Descaries produce la gran innovación, y se considera que las cosas sólo tienen existencia segura cuando son pensadas y el idealismo reemplaza al realismo.

En la metáfora del continente y conienido no se considera que las cosas vienen de fuera sino que son contenidos de ella, son ideas.

En la Edad Antigua se destaca la percepción, en la Edad Moderna la imaginación.

Al analizar estas dos metáforas básicas Ortega ha demostrado la gran importancia que éstas tienen en el desarrollo de la Filosofía.

En crmbos cosos una metáfora es el sustento de todo un sistema filosófico desarrollado a través de varios siglos y con implicancias en distintos campos: ontológico, gnoseológico, ético. elc. Pero, así mismo, ise ipjede adyertir, como lo afirma Vianu, que las metáforas han servido, ambién, para enmascarar la realidad. Assí, por ejenfpló,gla dondepdión deVlé Solnciencia como tabla cerina escondió o no permitió percibir el carácter activo de la conciencia que puede modificar las impresiones.

Para W. M. Urban, el símbolo o lenguaje melafísico es metáfora fundamental.

Por meláford fundomental entiende:

"precisamente es tipo de meláfora que se toma de dominios primarios e irieductibles de la experiencia" (26).

En Metafísica, la aplicación de cualquiera de los términos que se utiliza se hece en forma melalórica; así por ejemplo, una metafísica organicista empleará la noción o categoría de vida metafóricamente, una metafísica espiritualista 0 idealista emplearía melafóricamente la categoría de espíritu.

(26) Urban, Wibur Marshall, Lenguaje y Realidad, Fondo de Cultura Económica México 1952, Pág. 547. 
Para Urban todo pensamiento es metafórico, y cuún la ciencia opera con metáforas porque no puede hacerlo de olta manera. Pero la diferencia entre la ciencia y la metafísica está cieterminada por la operación científica. La ciencia utiliza la meláiora para poder operar sobre algo, así, si usa la metáfora de voluntad o propósito es porque de esa manera puede controlar la naturaleza.

\section{En cambio en:}

"metafísica la metáfora debe ser fundamental, esto es, debe tomarse de aquellos aspectos últimos e irreductibles de la realidad objeto de la experiencia sin la cual no podría haber experiencia" (27).

Las metáforas pues, reflejan la realidad y su uso se justifica plenamente en la metafísica.

"El desarrollo de este vocabulario (metafísica) no quiere de. cir que nuestro lenquaje ha llegado a ser absurdo o una triste especie de poesía, sino más bien que esie idioma peculiar ha llegado a ser necesatio para la adecuada expresión del sentido" (28).

Para Max Black, si se asume las concepciones sustitulivas y comparativas de la metálora (en los cuales se considera que una metáfora susptixeja un sjgpificado-liezal o lo compara con otro significado, tambien literal) se puede concluir que la me-

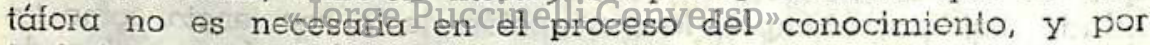
fanto tampoco en la filosolía ya que las

"metáforas de sustitución y de comparación puede reemplczarse por traducciones litercles (con la posible excepción de la catacresis) sin más que sacrificar parte del encon!o, vivacidad o ingenio del original, pero sin pérdida de contenide cognoscitivo" (29).

Sin embargo esias dos concepciones son consideradas por Black como insuficientes, y propone un tercer enfoque: el interactivo, en el cual se considera que en una meláfora hay una interacción mutua entre dos pensamienios. En una moláfora, nos dice Black, hay dos pensamientos de cosas distinias en actividad

(27) Urban, Ob. Cit, Pág. 550.

(28) Ibid, Pág. 523.

(29) Black, Modelos y Metáforas, Ed. Tecnos, Madrid, 1979, Pág. 55. 
simultánea y apoyados por una sola palabra o frase cuyo significcido es una resuliante de su interacción.

De este tipo de metáfora no se puede prescindir, pues no basta que se haga traducciones literales de la misma, ya que se habrá perdido la parte esencial de la metáfora que es la mulua vinculación que se ha producido entre los dos pensamientos que se han relacionado al producirse la metáfora.

En una meláfora, nos dice Black, se utiliza:

"un sistema especial de implicaciones (ya sea de 'lugares comunes' o un sistema especial establecido con visias a la finalidad del caso) como medio de seleccionar, acentuar y o:ganizar les relaciones en un campo distinto; y este empleo de un 'asunto subsidiario' para ayudar en la penetración del 'asunto principal' es una operación intelectual peculiar" (30).

Por tanlo, asumiendo la concepción interactiva de la meláfora se puede concluir que estas expmesiones son necesarias tonto en la ciencia, donde el modelo científico cumple similar función. como en la filosofía.

Una auténtica metáfora no puede ser reemplazada por una paráficisis literal porque lo úmico que se consigue es pédida de poder cognoscitivo pues a traducción literal no consigue hacemos penetrar en la cuestión como lo hacía la metáfora.

La explicación o desarrollo del fundamento de la metáfora, sin embargo, puedesen rumamentel yatiosa si no se le considera como un sustituto de-leligind.

Para Black, por Jtange Páscmetálórasisonar útiles y se justifican en la Filosofía porque nos permiten ve: un tema nuevo de una forma nueva, "el pensamiento metafórico es un modo peculiar de lograr una penetración intelectual que no ha de interpretarse como un sustituto omamental de un pensamiento llano" (31).

De chí que si bien algunos consideran peligroso el uso de metáforas en Filosofía,

"toda prohibición, de su empleo constituiría una restricción arbitraria y perjudicial de nuesira capaciadad de indagación" (32).

Para P. Wheelwright, la metáfora es parle de lo que é. denomina lenguaje tensivo o abierto y lo opone al esteno'enguaje

(30) Ibid, Pág. 55.

(31) Black, Ibid Pág. 232

(32) Ibid, Pág. 56. 
- lenguaje cerrado compuesto por términos estáticos ya sea por hábito o por prescripción voluntaria.

En el estenolenguaje cerrado por hábito el lenguaje pierde vitalidad $\mathrm{y}$ es susceptible de ambiguedades. En el estenolenguaje establecido por prescripción, por ejemplo en la ciencia y la lógica, se trata de evitar la ambigüedad consiguiendo la precisión semántica.

Ambos estenolenguajes son inadecuados para captar la realidad. El esienolenguaje cerrado por deficiencia porque se ha estereotipado y ha perdido vitalidad, y el lenguaje lógico, si bien es útil y necesario para determinados campos, no puede captar la realidad porque sólo se dirige a un aspecto de ella.

Aceptar que sólo el lenguaje lógico es válido es ccrer en el positivismo semántico, en el cual se planlea que las preguntas pertinentes a la verdad sólo pueden ser asumidos en este tipo de lenguaje y que cualquier otro planteamiento sólo obedece a búsquedas impulsivas de satisfacción emotiva.

Para Wheelwright:

"la inteligibilidad es múltiple Puede simplificársele en un esfuerzo por hacerse comprender ampliamente y puede confinársela, bajo responsabiliaad científica, al tipo de cosas que experimentos y obsefvaciones públicamente compatibles son capaces de demostran Pero en ambos casos algo queda fuera. Un todo definido no es nunca el todo. El anhelo del hombie por la verdad no puede ser totalmente satisfecho por el acuerdo público a la precisión iniachable" (33a).

El lenguaje máar gadecuadoel báconcapian ula realidad es pues, para este autor el lenguaje poético (y dentro de él la metáfora) debido a que la realidad es: a) presencial y tensiva en el sentido de que es un misterio y reclama respeto; b) es unitaria y se carcicteriza por la compenetración entre sus elementos y c) es perspectiva y latente y sólo se manifiesta a través de una oblicuidad simbólica. Ácemás el lenguaje poético, y por ende el metafórico, es el que permite captar la temporalidad.

El lenguaje poético que en parte crea y en parte expresa ciertos aspectos hasta entonces desconocidos e insospechados de lo que es constituye una perspectiva individual.

En conclusión, para Whellwright la metófora como parte del lenguaje poético permite penetrar en la realidad.

(33a) Wheelwright, Metáfora y Realidad, Ed. Espasa Calpe, Madrid 1979, Pág. 40. 
"Cualquier grado significaiivo del pensamiento es imposible sin lenguaje, como el lenguaje lo es a su vez sin actividad metafórica patente o velada, la concreción de ciertas metáforas en símbolos tensivos constituye una fase natural del proceso" (33b).

Para C. M. Turbayne el modelo o metáfoora es extraordinariamenle apta para esclarecer áreas que de otro modo podrían permanecer oscuras.

Sin embargo, considera que en la utilización de metáforas hay el peligro permanente de caer víctima de ella.

Turbayne nos dice que podemos pasar de utilizar una metáfora a ser utitlizados por ella. Esto se produce cuando una metáfora o modelo se toma en un sentido literal; cuando el modelo - metáfora utilizado se toma por la cosa misma.

Esto se da cuando se olvida que lo que está contenido en la metáfora es un supuesto y se toma como la realidad.

Todia metáfora supone un cruce de especies en cuanto se toma alco de una determinada clase y se le asigna a otra. En este sentido tiene un gran valor ilustrativo $\mathrm{y}$ explicativo.

Pero la metáfora se convierte en error y en medio de ocultamiento de la reclidad cuando este cruce de especies se toma como algo verdaderamenle exisiente. Ia metáfora se transforma de este modo en máscara de la verdad y de la realidad.

Dos ejemplos de esta situación se dan, según Turbayne, en Descartes y Newton.

Tanto Descartes como Newton desarrollaron procedimientos para describir el proceso de Id a naturcleza-y. luego confundieron los ingredientes de "sasgprocedimienteso con

Estos dos pensadores, dice Turbayne, cayeron víctimas de sus metáforas porque realizan cruce de especies o confusión de caiegorías. Entre éstcss: ción entre hechos.

a) La equiparación de la relación deductiva con la rela-

"Ambos hombres pensaron que las causas físicas producen la existencia de sus efectos, y que los efectos, necesariamente, proceden de las causas, ya que Newton descubrió los efectos como 'precedentes de ellas', y Descartes supuso que todos los fenómenos actuales del mundo debían producirse como necesaria consecuencia de las leyes del movimiento" (34).

(33 b) Ibid, Pág. 139.

(34) Turbayne, El Mito de la Meáfora, Fondo de Cultura Económica, México 1979, Pág. 64. 
De esta manera, una carcicierística definitoria del argumento deductivo se proyectó al mundo exterior y se sacó la conclusión que la naturaleza obedece a la lógica del método deductivo.

b) La inadvertidar identificación de explicación con la explicación física, y de ésta con la explicación causal, es decir la reduación de una a la otra, y

c) La injustificable identificación de la deducción con la computación o cálculo, olvidándose que lo que define a la deduc ción es la demostración y no la índole de los términos usados.

Estas confusiones de acuerdo a Turbayne, se dan tambien en las hipótesis. Muchas hipótesis implican el uso de metáforas, y por eso cuando se elige entre hipótesis rivales para explicar el mismo fenómeno lo que se está haciendo es elegir entre varias meláforas.

"La mayoria de fales hipótesis rivales implican el uso de me táforas y si éstas han pasado a las categorías de dogmas, suponen consepciones melafísicas rivales. En consecuencia so trata de elegir entre diferentes metáforas" (35),

Las nuevas teorías no sólo salvan las apariencias sino que crean otras nuevas. Y con frecuencia el corazón de las nuevas teorías está constiluido por otua meláforo.

Estas meláforas, por ejemplo, dice Turbayne se dan en el llamado modelo matemático 6 geométrico que vino a reemplazar la concepción o modelo anterior vigente en la Edad Media y Antigua.

Derivados de to que él llama cruce de especies on el modelo geométrico, se dan las siguientes caracierísticas metafóricas:

a) La deducción debe ser empleada más allá de la geomeiría abstracta para caplicarse a cualquier cosa.

b) La extensión debe ser tratada como la propiedad defi nitoria de! mundo físico, ya que no es otra cosa que res extensa.

Estas características son metáóricas porque so trasladen del lenguaje propio de la geomelría a lodo lo exisiente. Todo to existente se enfoca desde una perspectiva geométrica.

c) El movimiento es un modo de la extensión. Aunque esia característica no es derivade de la geometría también forma parte del modelo.

Este modelo geométrico o mecanicista domina el mundo fisico y llega a dominar el mundo biológico a? desplazar al vilalismo.

(35) Ibid, Pág. 86. 
"Por su genio, Descciries ha inventado una de las más grandes metáforas de la humanidad. Es como si, despertando de su sueño hubiera exclamado: Geometría sé mi metáfora". (36).

Por eso Turbayne considera que se debe tratan de "desnudar" las metáforas oculias que están implícitas en muchas concepciones y que son aceptadas por todos. Poner al descubierto una metáfora significa destruir antiguas asocicrciones, aunque esto muchas veces signifique crear nuevas, esto es crear nuevas metáforas, sin embargo la diferencia estará en que en este caso se estaría consciente de que se está ulilizando una metáfora. Se reconocería que en toda concepción lo que existe es una perspectiva prop'a, una manera de ver la realidad a través de nuevas metáforas.

Para Stehhen Pepper, toda gran concepción filosófica, sobre todo las concepciones cósmicas se han formado sobre 'a base de una hipótesis que el denomina "metáfora radical".

Las concepciones filosóficas se forman utilizando una analogía básica o meláfora radical.

El hombre al tratar de entender el mundo busca alrededor suyo para lograr algún indicio de comprensión y se detiene en alguna zona de sentido comin e intenta entender otras zonas en base a las semejanzas que pueds encontrar en ellas. Esto constituye la analogía bás'ca o "metáfora radical".

"Describe lo mejor que puede las características de esta zona, o si prefiere discierne su estructura y convierte una lista de sus caracierísticas estructurales en los conceplos básicos explicativos y deseriptivos CQ Ia quellanactemos conjunto de categorías). Pasara estudian a berende estas categorías todas las demás regiones fácticas, sometidas ya a crítica o no - trata de interpretar todos los hechos sobre ellas, pueden perfilarlas y reajustarlas, de modo que, de ordinario el conjunto de categorías cambia y se descrrolla. Como normalmente -Y, con bastante probabilidad al menos en parie también ne. cesariamente - la analogía básica o radical procede del sentido común se necesita desarrollar y afinar enormemente el conjunto de categorías para que resulten idóneas para una hipótesis de alcance ilimitado, algunas metáforas radicales demuestran ser más férilles que otras, tienen mayor caparidad de expansión y reajuste, y ellas son las que sobreviven frente a las demás y engendran las teorías del mundo relativormente idóneas" ( 37 ).

(36) Ibid, Pág. 89.

(37) Pepper, Etephen, "Wirld Hypothesis", University of California 1942, pág. 91 en Black, Ob. Cit, Pág. 42. 
Buscar objetos que ofrezcan paralelos con los que son in. ciertamente percibidos, utilizar lo más conocido es un proceder que se utiliza con mucha frecuencic..

"Este proceder anclógico parece ser caracleríslico de gran parte de las empresas intelectuales" (38).

Las metáforas radicales utilizadas en las concepciones filosóficas, son según Pepper las siguienies:

a) La metófora de la similaridad, que da lugar al formismo, llamado también realismo o idealismo platónico.

Platón, los escolásticos y muchos neorealistas son ejemplos de esta posición.

En estos sistemas la concepción de la verdad es la de la adecuación de lo afirmado con el objeto.

b) La metáíora de la máquina, de la cual se deriva el mecanismo llamado también naturalismo, maierialismo y hasta realismo.

La teoría de la Verdad se basa en un proceso inferencial y simbólico.

Ejemplos de esta posición son: atomismo de Demócrito, la concepción mecánica de la naturaleza (Galilelo, Descaries, Hobbes), el empirismo (Berkeley, Hume). Las especies de mecanismos dependerán del modelo de máquina tomado ya sea un reloj un dinamo, etc.

c) La metófora exprescida en un verbo (hacer, experimentar) en la que se dámichce raperiancia talafovimienio y al cambio. Se ubican dentro de estch posición Pierce, James, Bergson, Dewey, Head.

La concepción de la verdad aqui es la teoría operacional, y

d) La metáíora del organismo y la coherencia o integración que da origen al organicismo, llamado idealismo absoluio u objetivo.

Se ubican aquí Schellinv, Hegel, Bradley, Royce. La concepción de la verdad es aquí la teoría de la coherencia. (39).

Con referencia al problema que estamos tratando, Tudor Vianu considera que las metáforas constituyen una:

"primera forma de generalización entendida, además no a través de operaciones intelectuales sino mediante las intuiciones de la fantasía" (40).

(38) Pepper, Ob. cit, Pág. 91-92, en Black, Pág. 235,

(39) En Ferrater Mora, Ob. Cit, Pág. 399.

(40) Vianu, Ob. Cit, Pág. 94. 
La metáfora se revela como una etapa en el proceso de generalización en base a la semejanza pero no una generalización intelectual porque justamente la metáfora expresa aquellas semejanzas que un pensamiento teórico no puede expresar.

Además, no siempre hay una continuidad entre las metáforas poéticas y las generalizaciones de la inteligencia teórica.

"Hay metáforas, indudablemente, que reaparecen en las nociones fundamentales de la ciencia y de la filosofía ("fuerza", "energía", "espíritu universal", "el yo absoluto", etc. ), como iambién otras que no han evolucionado hacia la generalización leorética, juslamente la más características de la poesía. Así cuando el poeta señala que "los perfumes del lirio gritan", sorprende una semejanza entre un facior olfativo y otro acústico, una semejanza no susceptible de ser desarrollada en una generalización científica" (41).

Y es que para Vianu, en toda metáfora, sobre todo en la poética hay dos planos uno evidente $y$ otro latente, un aparente $y$ otro oculto.

El fondo latente de la metáfora no sólo es profundo sino que su profundidad se descrrolla progresivamente y coniinúa siendo ilimitadec.

Sin embargo, en el aspecto cognoscitivo la metáfora puede, aunque no siempre, ser el inicio de la forma de generalización, en base a la semejanza.

"Nuestro espíriu iblipta por las metâtoras poéticas, semejanzas que no prestpobien,usinembargoreas identidad profunda de todos los aspectos del mundo. La identidad profunda de los fenómenos es una hipólesis mística inútil, pero su semejanza es un hecho incontestable, base de todas las operaciones de generalización de la inteligencia" (42).

Vianu, considera, en otros pasajes de su obra, el papel que le ha correspondido a la metáfora en el desarrollo de la filosofía cuando dice:

"En efecto, no puede negarse el papel de la metáfora en el descrrollo del pensamiento filosófico si nos referimos al gran número e imporiancia de las circunstancias en que se ha recurrido a sus servicios. La historia del pensamiento es soli-

(41) Vianu, Loc. Cit.

(42) Vianu, Ob. Cit, Pág. 94. 
daria con la historia de la fantasía. Los esfuerzos cognoscinvos del hombre se han desarrollado paralelos a sus esfuerzos por ver e imaginar: estos dos esfuerzos ham colaborado durante mucho tiempo, y es probable que se solicitarán recíprocamente también en el futuro del espíritu humano" (43).

Pero, advierte Vianu, si bien la metáfora puede servir para captar la realidad, en ocasiones puede también ocultarla y agrega como ejemplo, las dos metáforas analizadas por Orlega y Gasset (metáforas de tabla rasa y continente y contenido) y la metáfora de la conciencia-espejo.

De acuerdo con esta metáfora, dice Vianu, se concibe el mundo como un todo completamente constituido, en el momenlo que la conciencia toma conocimiento de él. De esta metáfora se derivan una serie de dificultades filosóficas en cuanto se adscribe a la realidad características que solo pertenecen a su representación. Así por ejemplo en esta metáfora no se toma en cuenta que el hombre a través del trabajo modifica al mundo y por tanto no puede sólo reflejarlo, sí así fuera no existiría una historia del pensamiento pues la imagen del mundo se habría constituido desde el primer momento y no se habría modificado.

"Existe, sin embargo una historia del pensamiento, cuyas diferentes elapas está en relación con las fases de desarrollo de la sociedad, sus formas de imponerse a la realidad y de modificarla gradualmente hasta dominarla y conocerla cada vez más. Esia circunstancia esencial permanece, no obstante, cculta a causà dè lot moged de le coposencia-espejo, que de be ser eliminada" (44).inelli. Converso" que:

Por eso, Vianu, utilizando el mismo una metáfora considera

"la fantasía aparece, on ocasiones, como un vestido sumamente amplio para el pensamienio, incapaz de modelar todas sus formas, o como un vestido sumamente estrecho, que impone al pensamiento la necesidad de romperlo $\mathrm{Y}$ arrojarlo lejos de si" (45).

(43) Ibid Pág. 46

(44) Ibid Pág, 47.

(45) Loc. Cit. 